Business and Accounting Education Journal

\title{
PENGARUH PRAKTIK KERJA INDUSTRI, PRESTASI BELAJAR DAN MOTIVASI MEMASUKI DUNIA KERJA TERHADAP KESIAPAN KERJA SISWA KELAS XI SMK
}

\author{
Rizal Eko Wibowo, $₫$ Jarot Tri Bowo Santoso
}

Jurusan Pendidikan Ekonomi, Fakultas Ekonomi, Universitas Negeri Semarang, Indonesia

\begin{abstract}
Info Artikel
Sejarah Artikel:

Diterima,13 April 2020

Disetujui, 18 Juni 2020

Dipublikasikan, 31

Agustus 2020

Keywords:

Industry Working Practice,

Learning Achievement in the School, Motivation to Work and Work Readiness

Abstrak

Tujuan penelitian ini adalah untuk menguji pengaruh prakerin, prestasi belajar di sekolah, dan motivasi memasuki kerja terhadap kesiapan kerja. Populasi dalam penelitian ini adalah siswa kelas XI SMK Palebon Semarang. Jumlah populasi dari penelitian sebanyak 283 siswa dan sampel 166 siswa yang dihitung berdasarkan rumus Slovin dengan taraf kesalahan 5\%. Metode pengumpulan data menggunakan observasi, dokumentasi dan kuesioner. Metode analisis data menggunakan analisis regresi berganda, analisis uji hipotesis, dan analisis deskriptif persentase dengan menggunakan bantuan program SPSS for Windows Release 20. Hasil penelitian menunjukkan bahwa analisis regresi berganda diperoleh persamaan $\mathrm{Y}=30,773+0435 \mathrm{X} 1+$ $0,414 \mathrm{X} 2+0,2147 \mathrm{X} 3+$ e. Secara simultan prakerin, prestasi belajar di sekolah, dan motivasi memasuki dunia kerja berpengaruh positif dan signifikan terhadap kesiapan kerja sebesar 50,9\%. Sedangkan secara parsial untuk prakerin (praktik kerja industri) berpengaruh positif dan signifikan terhadap kesiapan kerja sebesar 40,83\%, prestasi belajar di sekolah berpengaruh positif dan siginifikan terhadap kesiapan kerja sebesar $2,75 \%$, dan motivasi memasuki dunia kerja berpengaruh berpengaruh positif dan siginifikan terhadap kesiapan kerja sebesar $2,72 \%$.
\end{abstract}

\footnotetext{
Alamat korespondensi:

Gedung L1 Lantai 1 FE Unnes

Kampus Sekaran, Gunungpati, Semarang, 50229

E-mail: niaaprilianurmawati@gmail.com
} 


\section{PENDAHULUAN}

Pendidikan adalah salah satu bentuk perwujudan dari seni dan budaya manusia yang dinamis dan syarat akan perkembangan. Oleh karena itu, perkembangan pendidikan hal yang memang seharusnya terjadi sejalan dengan perubahan budaya kehidupan.

Perkembangan ilmu pengetahuan dan teknologi serta tuntutan globalisasi secara bersama-sama telah mengakibatkan persaingan yang semakin ketat dalam penyediaan sumber daya manusia yang unggul. Untuk dapat terus mempertahankan daya saingnya, sumber daya manusia yang ada dituntut untuk terus meningkatkan pengetahuan, keterampilan, sikap, dan kompetensinya. Adanya tingkat kompetensi yang tinggi membuat seseorang cepat menyesuaikan perubahan yang ada di sekitarnya, termasuk dalam pergaulan, dalam pekerjaan, maupun dalam organisasi.

Tenaga kerja menengah yang professional sangat diperlukan untuk mendukung pertumbuhan industrialisasi maupun pertumbuhan ekonomi suatu Negara. Dikarenakan semakin banyak warga negara suatu bangsa yang terampil dan produktif maka semakin kuat kemampuan ekonomi negara. Berlaku sebaliknya, apabila semakin banyak warga suatu bangsa yang tidak terampil, maka semakin tinggi kemungkinan banyak penganguran. Kondisi ini akan menjadi beban ekonomi sehingga ekonomi suatu negara menjadi lemah.

Pendidikan dituntut untuk mampu menyiapkan tenaga kerja yang terampil guna memenuhi tuntunan kebutuhan tenaga kerja. Jenis pendidikan formal yang bertujuan untuk menyiapkan tenaga kerja yang terampil adalah Sekolah Menengah Kejuruan (SMK). Menurut Peraturan Pemerintah Republik Indonesia Nomor 29 Tahun 1990 Pasal 1, Pendidikan menengah kejuruan adalah pendidikan pada jenjang pendidikan menengah yang mengutamkan pengembangan kemampuan siswa untuk melaksanakan jenis pekerjaan tertentu.

$$
\text { Sekolah Menengah Kejuruan }
$$
merupakan salah satu lembaga pendidikan formal yang menyelenggarakan program pendidikan kejuruan dengan memberikan bekal pengetahuan dan ketrampilan kejuruan pada anak didiknya. Oleh sebab itu sekolah kejuruan diharapkan mampu menghasilkan tenaga terampil tingkat menengah yang siap pakai dalam bidang pekerjaan tertentu. SMK merupakan salah satu sekolah menengah yang mempersiapkan peserta didik dalam suatu bidang keahlian tertentu untuk memasuki lapangan kerja sesuai dengan tujuan pokok SMK. Untuk mempersiapkan peserta didik, SMK menerapkan pembelajaran yang disebut Pendidikan Sistem Ganda (PSG).

Menurut Bukit (2014) Pendidikan Sistem Ganda (PSG) merupakan sistem pendidikan kejuruan yang melaksanakan pembelajaran di sekolah dan industri, dimana pembelajaran di sekolah dan pelatihan di industri merupakan dua komponen yang berasal dari program yang tidak terpisahkan. Pada model pendidikan sistem ganda, ada dua pihak yang secara bersamaan menyelenggarakan suatu program pendidikan kejuruan. Kedua pihak tersebut adalah lembaga pendidikan dalam hal ini Sekolah Menengah Kejuruan dan lapangan kerja atau indutri (perusahaan) baik pemerintah maupun swasta.

Menurut Slameto (2015) kesiapan adalah keseluruhan kondisi seseorang yang membuat siap untuk memberi respon/jawaban didalam cara tertentu terhadap suatu situasi. Sedangkan Anoraga (2001) menyatakan bahwa kerja merupakan suatu yang di butuhkan oleh manusia. Kebutuhan itu bisa bermacam-macam, berkembang dan berubah dan bahkan seringkali tidak disadari oleh pelakunya. Jadi dapat dikatakan bahwa kesiapan kerja adalah keseluruhan kondisi seseorang yang membuatnya siap untuk memberikan respon atau jawaban terhadap situasi tertentu untuk memenuhi kebutuhan atas dirinya sendiri.

Kesiapan kerja dipandang sebagai kesiapan seseorang untuk mencari pekerjaan dan menentukan pekerjaan yang dipilih. Dengan kemampuan, pengetahuan, 
keterampilan, serta sikap yang dimiliki dalam diri siswa yang diperolehnya dari pengalaman belajar baik di sekolah, di rumah maupun dari pelaksanaan praktik kerja industi, bermanfaat ketika mereka memasuki dunia kerja. Hal ini senada dengan pendapat Winkel dan Hastuti (2007) yang menyatakan bahwa kesiapan kerja dipandang sebagai usaha untuk memantapkan seseorang mempersiapakan diri dalam hal pengetahuan, keterampilan, sikap dan nilai yang diperlukan dalam menekuni sebuah pekerjaan.

Menurut Slameto (2015) faktor - faktor yang mempengaruhi kesiapan adalah minat, motivasi sikap, dan kepribadian. Faktor yang mempengaruhi kesiapan kerja dapat dibedakan menjadi empat yaitu: (a) faktor psikologi (kondisi mental, emosi, keinginan atau minat, semangat atau motivasi, kesiapan berprestasi, kematangan berpikir); (b) faktor fisiologi (kondisi panca indra, sistem syaraf, otot - otot yang berfungsi dengan baik); (c) faktor pengalaman (pengetahuan dan keterampilan yang diperlukan dalam bekerja); (d) faktor ekstern (lingkungan, pendidikan, lingkungan keluarga, dan dunia kerja).

Menurut Bukit (2014), penyelenggaraan pendidikan dan pelatihan dengan pendekatan PSG bertujuan untuk: 1) Mendapatkan pengalaman bekerja dilini produksi. 2) Memahami sikap dan disiplin kerja. 3) Melalui praktik kerja nyata dilini produksi. 4) Mendapatkan kompetensi kejuruan sesuai dengan standar kopetensi yang di tuntut di dunia industri. 5) Mendapatkan kompetensi sosial yaitu bekerja sama dalam mengerjakan pekerjaan, mencari pemecahan terhadap kesulitan pekerjaan.

Praktik Kerja Industri (Prakerin) merupakan wujud nyata dari Pendidikan Sistem Ganda (PSG) untuk meningkatkan kesiapan kerja pada siswa SMK, yaitu dengan penyelenggaraan pendidikan kejuruan dengan perencanaan dan pelaksanaan pendidikan dilaksanakan melalui kemitraan antara sekolah dan dunia kerja. Prakerin dilaksanakan dengan menerjunkan langsung siswa pada dunia usaha/industri sesuai dengan bidangnya, dengan demikian siswa akan merasakan bagaimana kondisi pekerjaan yang akan dihadapinya dan memperoleh pengalaman-pengalaman baru sehingga dapat memberi bekal bagi siswa agar tidak canggung lagi dan lebih mudah dalam menyesuaikan pekerjaan suatu saat nanti. Melalui pelaksanaan kegiatan ini siswa akan mendapatkan pengalaman kerja sebagai bekal disaat terjun dalam dunia kerja. Dengan adanya praktek kerja industri siswa akan memiliki gambaran tentang dunia kerja yang sesungguhnya.

Alasan memilih kesiapan kerja siswa karena lulusan SMK pastilah setelah lulus nanti akan bekerja akan tetapi ada dari beberapa siswa yang antusias untuk melanjutkan ke perguruan tinggi. Maka dari beberapa jawaban siswa yang bervariasi tersebut akhirnya peneliti mengambil topik terkait kesiapan kerja siswa karena sudah jelas bahwa lulusan SMK diperuntukan setelah lulus bekerja.

Sedangkan Samsudi (2008) menyatakan bahwa idealnya lulusan SMK yang bisa langsung memasuki dunia kerja diharapkan sekitar $80 \%-85 \%$. Sementara itu dari jumlah lulusan SMK Palebon Semarang tahun pelajran 2016/2017 hanya sebesar 53,33\%. Kondisi ini mengindikasikan lulusan SMK Palebon Semarang belum memiliki kesiapan yang baik dalam memasuki dunia kerja. Artinya, sekolah masih belum mencapai tujuan yang diharapkan.

Hal ini juga memberikan pengertian bahwa kesiapan kerja pada setiap siswa tidak sama meskipun setiap siswa telah melakukan praktek kerja industri. Terkait dengan hal ini maka dapat di ketahui bahwa ada penyimpangan antara apa yang telah di rencanakan oleh SMK dengan kondisi yang terjadi di lapangan, karena SMK di harapkan mampu menciptakan lulusan yang mempunyai kesiapan kerja yang bagus dan sesuai dengan permintaan dari dunia kerja ataupun dunia industri.

Kesesuaian antara kompetensi akademik dan kompetensi keterampilan kerja diperlukan untuk membentuk kesiapan kerja maka praktik kerja industri dilakukan sesuai dengan bidang studinya, karena dalam dunia kerja keterampilan banyak dibutuhkan daripada 
kompetensi akademiknya. Praktik kerja industri dapat dimanfaatkan sebagai kesempatan siswa untuk meningkatkan keterampilan kerjanya sebelum memasuki dunia kerja nyata. Sejalan dengan pengertian diatas juga didukung oleh penelitian yang dilakukan oleh Fajriah dan Sudarma (2017) yang menyatakan bahwa pengalaman praktik kerja industri berpengaruh positif dan signifikan terhadap kesipan kerja siswa kelas XI Administrasi Perkantoran SMK Muhammadiyah Bobotsari. Dengan adanya praktek pengalaman kerja siswa dapat mengetahui job deskripsi pekerjaan di dunia industri sehingga hal tersebut dapat mendorong siswa untuk lebih mempersiapkan diri dan menambah motivasi memasuki dunia kerja pada siswa.

Sebagaimana yang dikemukakan oleh Sardiman (2008) bahwa motivasi merupakan salah satu faktor yang mempengaruhi kesiapan kerja seseorang. Sejalan dengan hal tersebut, Hamalik (2009) juga menyatakan bahwa motivasi merupakan salah satu faktor yang membentuk kesiapan seseorang. Sehingga dapat dikatakan bahwa motivasi kerja yang dimiliki siswa dapat membentuk kesiapan kerja dalam diri siswa tersebut.

Sejalan dengan hal tersebut, penelitian yang di lakukan oleh Kusnaeni dan Martono (2016) menyatakan bahwa terdapat pengaruh positif antara motivasi memasuki dunia kerja terhadap kesiapan kerja siswa SMK Bahakti Persada Kendal. Selain motivasi kerja dan praktik kerja industri, salah satu faktor yang mempengaruhi kesiapan kerja yang diungkapkan oleh Sukardi (1993) adalah prestasi belajar atau prestasi akademik.

Sudjana (2004) mengemukakan bahwa hasil belajar merupakan kemampuankemampuan yang dimiliki siswa setelah ia menerima pengalaman belajarnya. Setiap proses belajar mempengaruhi perubahan perilaku pada domain tertentu pada diri siswa, tergantung perubahan yang diinginkan terjadi sesuai dengan tujuan pendidikan. Hasil akhir dari belajar biasanya berupa skor nilai yang diberikan kepada siswa.

Jumlah skor yang diperoleh siswa menggambarkan hasil pencapaian dari proses belajar yang telah dilakukannya. Di dalam proses belajar, banyak skor yang diperoleh oleh siswa. Skor tersebut diperoleh dari berbagai tes yang dilakukan. Skor akhir dari hasil belajar tersebut adalah berupa skor rata - rata dari keseluruhan perolehan skor siswa. Skor tersebut disajikan dalam bentuk nilai di dalam buku raport sebagai laporan akhir dari perolehan hasil belajar siswa selama satu semester. Prestasi akademik siswa dapat menggambarkan penguasaan siswa terhadap pengetahuan dan keterampilan terhadap materi tertentu. Sejalan dengan hal tersebut penelitian yang dilakukan Royani (2015) menyatakan bahwa prestasi belajar berpengaruh secara simultan terhadap kesiapan kerja siswa SMK Palebon Semarang.

Tujuan penelitian ini adalah untuk mengetahui: (1) pengaruh praktik kerja industri, prestasi belajar disekolah, dan motivasi memasuki dunia kerja terhadap kesiapan kerja siswa kelas XI SMK Palebon tahun ajaran 2017/2018. (2) Pengaruh praktek kerja industri terhadap kesiapan kerja siswa kelas XI SMK Palebon tahun ajaran 2017/2018. (3) Pengaruh prestasi belajar disekolah terhadap kesiapan kerja siswa kelas XI SMK Palebon Semarang tahun pelajaran 2017/2018. (4) Pengaruh motivasi memasuki dunia kerja terhadap kesiapan kerja siswa kelas XI SMK Palebon tahun ajaran 2017/2018.

\section{METODE}

Jenis penelitian ini merupakan jenis penelitian deskriptif kuantitatif. Penelitian ini menggukan desain penelitian kausalitas (sebab-akibat). Populasi dalam penelitian ini sejumlah 283 siswa yang terbagi menjadi 7 kelas diantaranya Multimedia 1 sebanyak 39 siswa, Multimedia 2 sebanyak 39 siswa, Administrasi Perkantoran 1 sebanyak 37 siswa, Administrasi Perkantoran 2 sebanyak 45 siswa, Administari Perkantoran 3 sebanyak 46 siswa, Akutansi 1 sebanyak 36 siswa, Pemasaran 1 sebanyak 41 siswa. Sebenarnya jumlah keseluruan siswa kelas XI SMK Palebon Semarang tahun pelajaran 2017/2018 berjumlah 396 siswa akan tetapi sejumlah 113 siswa sedang melaksanakan praktek kerja industri dan untuk populasi yang terhitung 
hanya siswa yang aktif belajar di sekolah yaitu sebanyak 283 siswa dan jumlah sampel sebesar 166 siswa yang diambil menggunakan pendekatan rumus Slovin. Teknik pengambilan sampling yang dipergunakan dalam penelitian ini adalah Simple Random Sampling. Data dikumpulkan dengan metode dokumentasi dan kuesioner. Metode Analisis data berupa analisis deskriptif persentase, analisis regresi linear berganda dan uji $\mathrm{F}$ dan uji t.

\section{HASIL DAN PEMBAHASAN}

Analisis deskriptif persentase digunakan untuk mendeskripsikan variabel kesiapan kerja, praktik kerja industri, prestasi belajar, dan motivasi memasuki dunia kerja, yang terlihat pada table 1 berikut.

Tabel 1. Kategori Deskriptif Persentase Kesiapan Kerja

\begin{tabular}{lcccc}
\hline No & Interval & Frekuensi & Persen (\%) & Kriteria \\
1 & $52-60$ & 118 & $71,08 \%$ & Sangat Siap \\
2 & $43-51$ & 44 & $26,51 \%$ & Siap \\
3 & $34-42$ & 4 & $2,40 \%$ & Cukup Siap \\
4 & $25-33$ & 0 & $0,00 \%$ & Kurang Siap \\
5 & $<24$ & 0 & $0,00 \%$ & Tidak Siap \\
& Jumlah & 166 & $100 \%$ & \\
& & Rata-rata & & $\mathbf{5 3}$ \\
& & Kriteria & & Sangat Siap \\
\hline
\end{tabular}

Sumber: Data penelitian yang diolah

Hasil analisis deskriptif persentase kesiapan kerja dari 166 siswa yang dijadikan sampel dalam penelitian ini, 118 siswa $(71,08 \%)$ dalam kriteria sangat siap, 44 siswa
(26,51\%) pada kriteria siap, dan 4 siswa $(2,40 \%)$ menjawab pada kriteria cukup. Sedang nilai rata-rata sebesar 53,24 , hal ini menunjukan bahwa kesiapan kerja siswa di SMK Palebon termasuk dalam kategori sangat siap.

Tabel 2. Kategori Deskriptif Persentase Prakerin

\begin{tabular}{lcccc}
\hline No & Interval & Frekuensi & Persen (\%) & Kriteria \\
1 & $98-115$ & 71 & $42,77 \%$ & Sangat Baik \\
2 & $80-97$ & 93 & $56,02 \%$ & Baik \\
3 & $62-79$ & 2 & $1,20 \%$ & Cukup \\
4 & $44-61$ & 0 & $0,00 \%$ & Kurang Baik \\
5 & $<43$ & 0 & $0,00 \%$ & Tidak Baik \\
& Jumlah & 166 & $100 \%$ & \\
& & Rata-rata & & $\mathbf{9 6 , 1 6}$ \\
& & Kriteria & & Baik \\
\hline
\end{tabular}

Sumber: Data penelitian yang diolah

Hasil analisis deskriptif persentase Prakerin dari 166 siswa yang dijadikan sampel dalam penelitian ini, 71 siswa $(42,77 \%)$ dalam kriteria sangat baik, 93 siswa $(56,02 \%)$ pada kriteria baik, dan 2 siswa (1,20\%) pada kriteria cukup. Sedangkan nilai rata-rata Prakerin sebesar 96,16, hal ini menunjukan bahwa Prakerin termasuk dalam kategori baik. 
Tabel 3. Kategori Deskriptif Persentase Prestasi Belajar

\begin{tabular}{lcccc}
\hline No & Interval & Frekuensi & Persen (\%) & Kriteria \\
1 & $92-100$ & 0 & $0,00 \%$ & Sangat Baik \\
2 & $82-91$ & 24 & $14,45 \%$ & Baik \\
3 & $72-81$ & 142 & $85,54 \%$ & Cukup \\
4 & $62-71$ & 0 & $0,00 \%$ & Kurang Baik \\
5 & $<52$ & 0 & $0,00 \%$ & Tidak Baik \\
& Jumlah & 166 & $100 \%$ & \\
& & Rata-rata & & $\mathbf{8 0 , 3 1}$ \\
& & Kriteria & & Cukup \\
\hline
\end{tabular}

Sumber: Data penelitian yang diolah

Hasil analisis deskriptif persentase prestasi belajar dari 166 siswa yang dijadikan sampel dalam penelitian ini, 24 siswa $(14,45 \%)$ mempunyai kriteria baik, sedangkan 142 siswa $(85,54 \%)$ mempunyai prestasi belajar kriteria cukup. Sedangkan nilai rata-rata sebesar prestasi belajar sebesar 80,31, hal ini menunjukan bahwa prestasi belajar siswa kelas XI SMK Palebon Semarang Tahun Pelajaran 2017/2018 termasuk dalam kriteria cukup.

Tabel 4. Kategori Deskriptif Persentase Motivasi Memasuki Dunia Kerja

\begin{tabular}{lcccc}
\hline No & Interval & Frekuensi & Persen (\%) & Kriteria \\
1 & $60-77$ & 138 & $83,13 \%$ & Sangat Baik \\
2 & $49-59$ & 28 & $16,87 \%$ & Baik \\
3 & $38-48$ & 0 & $0,00 \%$ & Cukup \\
4 & $27-37$ & 0 & $0,00 \%$ & Kurang Baik \\
5 & $<26$ & 0 & $0,00 \%$ & Tidak Baik \\
& Jumlah & 166 & $100 \%$ & \\
& & Rata-rata & & $\mathbf{6 2 7}$ \\
& & Kriteria & & Sangat Baik \\
\hline
\end{tabular}

Sumber: Data penelitian yang diolah

Hasil analisis deskriptif persentase motivasi memasuki dunia kerja dari 166 siswa yang dijadikan sampel dalam penelitian ini, 138 siswa $(83,13 \%)$ termasuk kriteria sangat baik dan 28 siswa $(16,87 \%)$ termasuk pada kriteria baik. Sedangkan nilai rata-rata sebesar 62,87 hal ini menunjukan bahwa motivasi memasuki dunia kerja termasuk dalam kategori sangat baik.

Hasil analisis regresi linier berganda dengan kesiapan kerja sebagai variabel dependen dan Prakerin, prestasi belajar, dan motivasi memasuki dunia kerja sebagai variabel independen sebagai berikut.

Tabel 5 : Analisis Regresi Linier Berganda

\begin{tabular}{|c|c|c|c|c|c|c|}
\hline \multicolumn{7}{|c|}{ Coefficients $^{\mathrm{a}}$} \\
\hline \multirow{2}{*}{\multicolumn{2}{|c|}{ Model }} & \multicolumn{2}{|c|}{$\begin{array}{l}\text { Unstandardized } \\
\text { Coefficients }\end{array}$} & \multirow{2}{*}{$\begin{array}{c}\text { Standardized } \\
\text { Coefficients } \\
\text { Beta }\end{array}$} & \multirow[b]{2}{*}{$\mathrm{t}$} & \multirow[b]{2}{*}{ Sig. } \\
\hline & & $\mathrm{B}$ & Std. Error & & & \\
\hline \multirow[t]{3}{*}{1} & (Constant) & 30,773 & 16,057 & & $-1,916$ &, 057 \\
\hline & PKR & 435 & , 041 & ,638 & 10,571 &, 000 \\
\hline & $\mathrm{PP}$ & ,414 & ,193 & ,118 & 2,145 & ,033 \\
\hline
\end{tabular}


a. Dependent Variable: KK

Sumber: Data penelitian yang diolah

Berdasarkan tabel 5 diperoleh persamaan regresi linear berganda sebagai berikut.

\section{Kesiapan Kerja $=30,773+0,435$ Prakerin + 0,414 Prestasi Belajar + 0,147 Motivasi Memasuki Dunia Kerja}

Uji simultan dilakukan untuk menunjukan besar pengaruh semua variabel independen secara bersama-sama terhadap variabel dependen. Hasil uji $\mathrm{F}$ menunjukkan bahwa $\mathrm{F}$ hitung $=58,106$ dengan signifikasi $0,000<0,05$. Hasil ini menunjukkan bahwa hipotesis 1 diterima. Berdasarkan hasil tersebut, maka hipotesis 1 dalam penelitian yang berbunyi "Ada pengaruh praktik kerja industri (Prakerin), prestasi belajar dan motivasi memasuki dunia kerja terhadap kesiapan kerja siswa kelas XI SMK Palebon Semarang tahun pelajaran 2017/2018", diterima.

Variabel praktik kerja industri diperoleh nilai signifikansi sebesar $0,000<0,05$ dengan $\mathrm{t}$ hitung yang diperoleh sebesar 10,571 maka hipotesis 2 diterima. Ada pengaruh praktik kerja industri terhadap kesiapan kerja siswa sebesar 40,83\% dilihat dari $\mathrm{r}^{2}$. Variabel prestasi belajar diperoleh nilai signifikansi sebesar $0,033<0,05$ dengan $t$ hitung yang diperoleh sebesar 2,135 maka hipotesis 3 diterima. Ada pengaruh prestasi belajar terhadap kesiapan kerja siswa sebesar $2,75 \%$ dilihat dari $\mathrm{r}^{2}$. Variabel motivasi memasuki dunia kerja diperoleh nilai signifikansi sebesar 0,034< 0,05 dengan $t$ hitung yang diperoleh sebesar 2,477 maka hipotesis 4 diterima. Ada pengaruh motivasi memasuki dunia kerja terhadap kesiapan kerja siswa sebesar 2,72\% dilihat dari $\mathrm{r}^{2}$.

\section{Pengaruh Praktik Kerja Industri, Prestasi Belajar dan Motivasi Memasuki Dunia Kerja Terhadap Kesiapan Kerja}

Berdasarkan hasil penelitian menggunakan aplikasi SPSS For Windows 20 dalam analisis regresi linier berganda: $\mathrm{Y}=$
$30,773+0,435 \mathrm{X}_{1}+0,414 \mathrm{X}_{2}+0,147 \mathrm{X}_{3}+\mathrm{e}$ menunjukkan bahwa secara simultan terdapat pengaruh yang positif dan signifikan antara prakerin (praktik kerja industri), prestasi belajar dan motivasi memasuki dunia kerja terhadap kesiapan kerja siswa kelas XI SMK Palebon Semarang tahun ajaran 2017/2018. Artinya apabila prakerin (praktik kerja industri), prestasi belajar dan motivasi memasuki dunia kerja meningkat maka kesiapan kerja akan meningkat, sebaliknya apabila prakerin (praktik kerja industri), prestasi belajar dan motivasi memasuki dunia kerja menurun maka kesiapan kerja akan menurun.

Besarnya pengaruh antara prakerin (praktik kerja industri), prestasi belajar, dan motivasi memasuki dunia kerja terhadap kesiapan kerja siswa kelas XI SMK Palebon Semarang tahun ajaran 2017/2018 secara simultan dapat dilihat dari hasil koefisien determinasi simultan yang diperoleh dari adjusted $\mathrm{R}$ square sebesar 50,9\% dan sisanya 49,1\% dipengaruhi oleh variabel lain yang tidak diteliti dalam penelitian ini.

Melihat dari hasil uji hipotesis secara simultan, nilai $\mathrm{F}$ hitung untuk variabel prakerin (praktik kerja industri), prestasi belajar dan motivasi memasuki dunia kerja sebesar 58,106 dengan signifikansi $0,000<0,05$ yang artinya nilai t hitung signifikan dan $\mathrm{Ha}_{1}$ yang berbunyi "semakin tinggi prakerin (praktik kerja industri), prestasi belajar dan motivasi memasuki dunia kerja maka akan semakin tinggi tingkat kesiapan kerja siswa kelas XI SMK Palebon Semarang tahun ajaran 2017/2018 "diterima".

\section{Pengaruh Praktik Kerja Industri Terhadap Kesiapan Kerja}

Besarnya pengaruh prakerin (praktik kerja industri) terhadap kesiapan kerja siswa sebesar $40,83 \%$ yang diperoleh dari hasil koefisien determinasi parsial. Sedangkan jika dilihat dari hasil uji hipotesis secara parsial, nilai t hitung untuk variabel praktik kerja industri sebesar 10,571 dengan signifikansi $0,00<0,05$ yang artinya nilai t hitung signifikan dan $\mathrm{Ha}_{2}$ yang berbunyi "semakin tinggi prakerin (praktik kerja industri), maka semakin tinggi tingkat kesiapan 
kerja siswa kelas XI SMK Palebon Semarang tahun ajaran 2017/2018, diterima.

Hasil analisis deskripsi persentase data penelitian ini menunjukkan bahwa prakerin (praktik kerja industri) diukur dengan menggunakan 5 indikator yaitu tahap persiapan, tahap peragaan, tahap peniruan, tahap praktik, dan tahap evaluasi. Berdasarkan 5 indikator tersebut, jawaban responden menunjukkan berada dalam kategori baik dengan nilai persentase sebesar $56 \%$.

Hasil penelitian ini sesuai dengan pendapat Star et al. dalam Wena (2009) bahwa pendidikan kejuruan mempunyai kaitan erat dengan dunia kerja atau industri, maka pembelajaran dan pelatihan praktik memegang peranan kunci untuk membekali lulusannya agar mampu beradaptasi dengan lapangan kerja. Kesiapan kerja juga dipandang sebagai usaha untuk memantapkan seseorang mempersipkan diri dalam hal pengetahuan, keterampilan, sikap serta nilai yang diperlukan dalam menekuni sebuah pekerjaan (Winkel dan Hastuti 2007). Selain itu, diperkuat temuan Triani dan Arief (2016) bahwa ada pengaruh positif dan signifikan prakerin terhadap kesiapan kerja siswa SMK kompetensi Keahlian Akuntansi sebesar $27,5 \%$.

\section{Pengaruh Prestasi Belajar Terhadap Kesiapan Kerja}

Besarnya pengaruh prestasi belajar terhadap kesiapan kerja siswa sebesar 2,75\%. Dilihat dari nilai rata-rata raport siswa, semua siswa mendapatkan nilai di atas KKM dimana KKM di SMK Palebon semarang adalah 75 . Sedangkan hasil uji analisis deskriptif, semua siswa telah memperoleh nilai di atas 75 yang artinya prestasi belajar disekolah berada pada kategori tuntas. Hal ini menunjukan bahwa nilai yang di peroleh selama mengikuti/mendalami mata pelajaran di sekolah dapat meningkatkan kesiapan kerja siswa SMK Palebon.

Hasil penelitian ini sesuai dengan pendapat Sudjana (2004) yang mengemukakan bahwa hasil belajar merupakan kemampuankemampuan yang dimiliki siswa setelah ia menerima pengalaman belajarnya. Setiap proses belajar mempengaruhi perubahan perilaku pada domain tertentu pada diri siswa, tergantung perubahan yang diinginkan terjadi sesuai dengan tujuan pendidikan. Hasil akhir dari belajar biasanya berupa skor nilai yang diberikan kepada siswa. Hasil penelitian ini diperkuat temuan Baiti (2014) bahwa ada pengaruh positif dan signifikan prestasi belajar terhadap kesiapan kerja siswa SMK sebesar $6,4 \%$.

\section{Pengaruh Motivasi Memasuki Dunia Kerja Terhadap Kesiapan Kerja}

Besarnya pengaruh motivasi memasuki dunia kerja terhadap kesiapan kerja siswa sebesar 2,72\% yang diperoleh dari hasil koefisien determinasi parsial. Hasil analisis deskripsi persentase menunjukkan bahwa motivasi memasuki dunia kerja diukur dengan menggunakan 6 indikator yaitu hasrat dan keinginan, dorongan dan kebutuhan, harapan dan cita-cita, penghormatan atas diri, lingkungan yang baik, dan kegiatan yang menarik. Berdasarkan 6 indikator tersebut, jawaban responden menunjukan berada dalam kategori sangat baik dengan nilai persentase sebesar $83,13 \%$.

Hasil penelitian ini sesuai dengan pendapat Sardiman (2008) yang mengemukakan bahwa motivasi merupakan salah satu faktor yang mepengaruhi kesipan kerja seseorang. Sejalan dengan hal tersebut, Hamalik (2009) juga menyatakan bahwa motivasi merupakan salah satu faktor yang membentuk kesiapan seseorang. Hasil penelitian ini diperkuat dengan temuan Yuliana (2015) bahwa ada pengaruh positif dan signifikan motivasi memasuki dunia kerja terhadap kesiapan kerja siswa SMK sebesar $10,43 \%$.

\section{SIMPULAN}

Simpulan penelitian ini yaitu: (1) Secara simultan ada pengaruh yang positif dan signifikan Prakerin, prestasi belajar dan motivasi memasuki dunia kerja terhadap kesiapan kerja siswa kelas XI SMK Palebon Semarang tahun ajaran 2017/2018. (2) Secara parsial ada pengaruh yang positif dan signifikan Prakerin terhadap kesiapan kerja siswa kelas XI SMK Palebon Semarang tahun ajaran 2017/2018. (3) Ada pengaruh 
positif dan signifikan prestasi belajar terhadap kesiapan kerja siswa kelas XI SMK Palebon Semarang tahun ajaran 2017/2018. (4) Ada pengaruh yang positif dan signifikan antara motivasi memasuki dunia kerja terhadap kesiapan kerja siswa kelas XI SMK Palebon Semarang tahun pelajaran 2017/2018

\section{DAFTAR PUSTAKA}

Anoraga, Pandji. (2001). Psikologi Kerja. Jakarta: Rineksa Cipta.

Baiti, Ahmad Awaludin. (2014). Pengaruh Pengalaman Praktik, Prestasi Belajar Dasar Kejuruan dan Dukungan Orang Tua Terhadap Kesiapan Kerja Siswa SMK. Jurnal Pendidikan Vokasi, Vol 4, Nomor 2, Juni

Bukit, Marsiam. (2014). Strategi dan Inovasi Pendidikan Kejuruan. Bandung: Alfabeta

Hamalik, Oemar. (2009). Proses Belajar Mengajar. Jakarta: Bumi Aksara.

Fajriah, Ufi Naeli dan Ketut Sudarma. (2017). Pengaruh Praktik Kerja Industri, Motivasi Memasuki Dunia Kerja, dan Bimbingan Karir pada Kesiapan Kerja Siswa. Diambil dari: http://journal.unnes.ac.id/sju/index.ph p/eeai.

Kusnaeni, Yuyun dan S, Martono. (2016). Pengaruh Persepsi Tentang Praktik Kerja Lapangan, Informasi Dunia Kerja dan Motivasi Memasuki Dunia Kerja Terhadap Kesiapan Kerja Siswa SMK. http://journal.unnes.ac.id/sju/index.ph p/eeaj

Peraturan Pemerintah Republik Indonesia Nomor 29 Tahun 1990 Tentang Pendidikan Menengah

Royani, Ide. (2015). Peran Motivasi dalam Memediasi Pengaruh Praktik Kerja Industri dan Prestasi Akademik Terhadap Kesiapan Kerja Studi Kasus pada Siswa Kelas XI Akuntansi di SMK Palebon Semarang Tahun 2014/2015. Diambil https://lib.unnes.ac.id.

Sardiman, AM. (2008). Interaksi dan Motivasi Belajar Mengajar. Jakarta: Raja Grafindo Persada.

Slameto. (2015). Belajar dan Faktor-faktor yang Mempengaruhinya. Jakarta: Rineka Cipta.

Sudjana, Nana. (2004). Penilaian Hasil Proses Belajar Mengajar. Bandung: Remaja Rosdakarya Offiset.

Sukardi, D. K. (1993). Bimbingan Karir di SekolahSekolah. Jakarta Timur: CV. Ghalia Indonesia.

Samsudi. (2008). Pendidikan Vokasi: Sebuah Investasi Membangun Generasi Kompeten. Makalah Pidato Ilmiah dalam Rangka Dies Natalis Unnes ke 43. UNNES

Triani, Diyah dan Sandi Arief. (2016). Pengaruh Praktik Kerja Industri, Hasil Belalajar Mata Pelajaran Akuntansi, dan Motivasi Memasuki Kerja Terhadap Kesiapan Kerja Siswa Akuntansi. Diambil dari: http://journal.unnes.ac.id/sju/index.ph p/eea.

Wena, Meda. (2009). Strategi Pembelajaran Inovatif Kontemporer Suatu Tinjauan Konseptual Operasional. Jakarta. Bumi Aksara.

Winkel, W. S dan M. M. Sri Hastuti. (2007). Bimbingan dan Konseling di Institusi Pendidikan. Yogyakarta: Media Abadi.

Yuliana, Ika. (2015). Pengaruh Pengalaman Praktik Kerja Industri, Motivasi Memasuki Dunia Kerja dan Kemampuan Softkills Terhadap Kesiapan Kerja Siswa Kelas XII Kopetensi Keahlian Akuntansi di SMK 2 Semarang Tahun Ajaran 2014/2015. Diambil dari: https://journal.unnes.ac.id. 